\title{
CORRESPONDENCE
}

\section{Creative engineers}

SIR - Darnbrough (Nature 18 March, p.192) and Austen (Nature 25 March, p.284) both miss, or intentionally obfuscate, my analogy about the evolution of aeroplanes and biological evolution. Both processes lead from the simple to the highly complex. Hoyle and Wickramasinghe, not I, chose the aeroplane simile and implied that evolutionists believe that "higher life forms evolved by chance", and that a gene "might be chosen from $10^{20}$ nucleotide sequences of the appropriate length". This implies that large complex proteins appear without any intermediate stages.

Actually, proteins are thought to have evolved by the joining together of short polypeptides, as pointed out by me (Molecules and Evolution, Columbia University Press, pp. 222-229, 1960), and further explained by Rout (Nature 18 March, p.192). Ycas has given striking examples of this process in "periodic" proteins such as collagen and keratin (J. molec. Evol. 2, 17; 1972). Lengthening was probably by duplication and recombination in DNA, followed by an accumulation of point mutations.

Obviously the evolution of aeroplanes, completed in a few years, was a product of the creative genius of engineers. The point was that the Boeing 747 did not suddenly appear on the scene. In contrast, biological evolution took millions of times as long, and was impelled by slow, insensate natural phenomena. Austen says that "without a Creator, atoms and molecules, which $\mathrm{He}$ created, are still atoms and molecules". How could atoms and molecules exist without a Creator if $\mathrm{He}$ created them?

THOMAS H. JUKES

University of California,

Berkeley, California, USA

\section{A thermal history}

SIR - Many letters in recent issues of Nature show little unanimity about the mechanisms or rate of evolution. There may, however, be agreement that organisms do not adapt to, or evolve for, life in non-existent environments: nor do they retain capacities needed in an environment in which they no longer live.

In the course of their mainly reasonable discussion on the probable thermal history of Earth, while exposed to a steadily increasing rate of inflow of solar energy, Lovelock and Whitfield (Nature 296, 561; 1982) quote the observation that $50^{\circ} \mathrm{C}$ is the "critical upper limit for most life" as a factor supporting their thesis that the overall temperature never fluctuated greatly from today's values. That particular piece of evidence is not very cogent. Hot environments, such as hot springs and submarine spreading centres, are small and, from an evolutionary and geological standpoint, evanescent. Circumstances do not now exist that favour the evolution of organisms adapted to life at high temperatures, nor the persistence of that ability if it existed earlier.

The fossil record tells us nothing about the thermal preferences of very early organisms.
Biological potentialities should not be underrated. Enzymes vary in thermostability so, if granted several million years of undisturbed occupation of an extensive hot site, there is good reason to expect the emergence of proteins more robust than those with which we are familiar. It is not just a coincidence that the boiling point of water under today's atmospheric pressure is the limit beyond which no organisms are known to be able to live, and that very few organisms can approach that temperature. There would be no advantage in the ability to exceed that temperature - or in many organisms adapting to it. And proteins are not the only conceivable vehicles for quasi-enzyme activity. Had there been a prolonged period when the overall temperature was greater than it is now, there is no reason to assume that organisms adapted to it could not have existed. Recognition of this possibility extends the scope of discussion about the origins of life. N. W. PIRIE

Rothamsted Experimental Station, Harpenden, Herts, UK

\section{Not unilaterally}

SIR - Though you published an editorial (Nature 1 April, p.380) commenting on the three letters contained in that issue replying to the editorial of 18 February (p.542) criticizing the use of professional reputation to give credibility as it were through the backdoor, to causes like disarmament, you failed to notice the essential sophism of the points in the letters. And as this sophism is of much wider consequence than the matters addressed in these letters, affecting the whole popular movement of opinion on a subject of great importance, it deserves attention and debate.

The error is seen in the tendency to deduce from the articulated description of the horrors of nuclear war, the wrongness of, and hence the desirability to prohibit, nuclear arms. It was not felt by any of your correspondents necessary, beyond showing how awful the results of nuclear war are, to argue that disarmament has any relevance to diminishing the risks of war.

It seems to me that those who in supporting disarmament say that they are primarily concerned to achieve a wider public awareness of the consequences of nuclear war, are in fact advocating response rather than consideration. They imply by arguing how wrong nuclear wars are, that the obvious conclusion is that to prepare for the eventuality of such a war is also wrong. To argue like this is to take advantage of the association of ideas in the mind, but to evade the rational consideration of what causes war.

Although it is not my intention to argue for nuclear weapons, only to point out that the greater salience of an idea does not excuse a failure to demonstrate the validity of an argument, it is important to remember that wars are initiated in the expectation, however misconceived, that winning them is possible. Nuclear weapons as presently shared between the superpowers do not allow such misconceptions, though after unilateral disarmament one fears they could.

London NW3, UK

\section{Propaganda war}

SIR - Your leading article of 1 April (p.380) headed "Professional propaganda" complains that professional groups, such as physicians who state that the threat of nuclear war currently presents the most urgent challenge to preventive medicine, do not at the same time offer alternative political and military solutions to the problems of arms control and defence. I suspect that if they were to try to do so you would censure them for making pronouncements on subjects beyond their expertise.

You would, however, be mistaken to presume that those who take the step of joining organizations such as Physicians for Social Responsibility in the United States or the Medical Campaign against Nuclear Weapons in the United Kingdom are politically ignorant. It is because they know enough to be unconvinced by assurances that nuclear weapons are necessary and for the best that they try to bring home to the public and to politicians the dangers of regarding such weapons as acceptable instruments of policy. Similar concerns also stir physicians in other countries, both East and West. At a congress held in Cambridge recently by International Physicians for the Prevention of Nuclear War (an arrogant title, perhaps, but not inaccurate) some two hundred eminent participants from 31 countries were unanimous in concluding that nuclear war - whether intended or resulting from tragic accident - would be catastrophic for any countries involved and might have dire consequences for humankind, that the medical services could have only a marginal effect in mitigating the suffering of immediate survivors, and that it was a continuing duty to bring this home to the public and to politicians in their own countries.

The congress agreed some carefully prepared statements, among them letters to President Reagan and Chairman Brezhnev which included the following outright recommendations for political action:

"We believe that action must be taken now to prevent nuclear war and to relieve the consequences of the arms race. We urge that as a first step, the nuclear powers cease all further production, testing, and deployment of nuclear weapons and their delivery systems. This should be accompanied by mutually acceptable methods of verification. We further urge that all nuclear powers unequivocally renounce the use of such weapons, and agree to prevent their introduction into any conflict. We advocate effective bilateral and multilateral negotiations on the limitation, reduction, and ultimate elimination of nuclear weapons.

We are aware that negotiations have been in progress for many years with essentially no apparent effect on the arms race. While we welcome any initiative by either side to reduce its stock of nuclear weapons, we recognize that they are likely to be eliminated only by negotiation. We must again urge that such negotiations be pursued seriously and continuously until they succeed." 